Biol. Neonate 1987;52:I-VI

\title{
Contents, Vol. 52, 1987
}

\section{Contents Vol. 52,1987}

No. 1 Original Paper

Long-Term Variation in Oxygen Consumption Rate in Preterm Infants

Roberts, S.B.; Murgatroyd, P.R.; Crisp, J.A.; Nohria, V.; Schlingenseipen, K.-H.; Lucas, A. 1

Human Umbilical Arteries and Veins: Generation of Leukotrienes and Response to Exogenous

Leukotrienes

Piper, P.J.; Levene, S 9

Reliability of Urinary N-Acetyl-ß-Z > -Glucosamínidase as an Indicator of Renal Tubular

Damage in Neonates

Watanabe, K.; Kojima, T.; Fukuda, Y.; Ohbayashi, K.; Kobayashi, T.; Iwase, S.;

Kobayashi, Y 16

Effects of $\mathrm{pH}$ and Hypoglycemia on Bilirubin Cytotoxicity in vitro

Sugita, K.; Sato, T.; Nakajima, H 22

Development of Enzymes of Glycerol Metabolism in Human Fetal Liver

Sadava, D.; Depper, M.; Gilbert, M.; Bernard, B.; McCabe, E.R.B 26

Effect of Dexamethasone on the Adenylate Cyclase System of Cultured Hepatocytes of

Fetal Rats

Nishida, N.; Takeuchi, T 33

Perinatal Hamster Gonadal Androgen and Estradiol Production in vitro and Response

tohCG

Vomachka, A.J.; DiMario, K.B 40

Biochemical Maturation of Fetal Rat Lung: A Comprehensive Study Including Surfactant

Determination

Bourbon, J.R.; Farrell, P.M.; Doucet, E.; Brown, D.J.; Valenza, C 48

No. 2 Review

Developmental Expression and Modification of Genes

Benvenisty, N.; Reshef, L 61

Original Paper

Carnitine Concentrations in the Milk of Different Species and Infant Formulas

Penn, D.; Dolderer, M.; Schmidt-Sommerfeld, E 70

Ketogenesis in Hypoglycemic Neonates. Carnitine and Dicarboxylic Acids in Neonatal

Hypoglycemia

Sann, L.; Divry, P.; Cartier, B.; Vianey-Laud, C; Maire, 180

Effect of Protein Malnutrition and Maternal Caffeine Intake on the Growth of Fetal Rat

Brain

Yazdani, M.; Tran, T.H.; Conley, P.M.; Laurent, J., Jr.; Nakamoto, T 86

S. Karger - Medical and Scientific Publishers

Basel — München · Paris · London · New York · New Delhi — Singapore · Tokyo · Sydney

Drug Dosage 
The authors and the publisher have exerted every effort to ensure that drug selection and dosage set forth in this text are in accord with current recommendations and practice at the time of publication. However, in view of ongoing research, changes in government regulations, and the constant flow of information relating to drug therapy and drug reactions, the reader is urged to check the package insert for each drug for any change in indications and dosage and for added warnings and precautions. This is particularly important when the recommended agent is a new and/or infrequently employed drug.

All rights reserved.

No part of this publication may be translated into other languages, reproduced or utilized in any form or by any means, electronic or mechanical, including photocopying, recording, microcopying, or by any information storage and retrieval system, without permission in writing from the publisher or, in the case of photocopying, direct payment of a specified fee to the Copyright Clearance Center (see 'Information for Readers and Subscribers').

(C) Copyright 1987 by

S. Karger AG, P.O. Box, CH-4009 Basel (Switzerland) Printed in Switzerland by Thür AG Offsetdruck, Pratteln

Contents

$\mathrm{V}$

Glucose Homeostasis in the Newborn: Effects of an Intravenous Glucose Infusion in Nor mal and Intra-Uterine Growth-Retarded Neonatal Piglets

Flecknell, P.A.; Wootton, R.; Royston, J.P.; John, M 205

Effects of Chronic Maternal Dexamethasone Treatment on the Hormones of the Hypothalamo-Pituitary-Adrenal Axis in the Rat Fetus

Dupouy, J.-P.; Chatelain, A.; Boudouresque, F.; Conte-Devolx, B.; Oliver, C 216

Lipid Peroxidation and Vitamin E Levels during Pregnancy in Rats

Yoshioka, T.; Motoyama, H.; Yamasaki, F.; Ando, M.; Takehara, Y.; Yamasaki, M. . 223

Lung as a Possible Additional Target Organ for Vitamin D during Fetal Life in the Rat

Nguyen, M.; Guillozo, H.; Garabédian, M.; Balsan, S 232

No. 5 Original Paper

Common Carotid Artery Flow Velocity Measurements in the Newborn Period with Pulsed

Doppler Technique

Raju, T.N.K.; Go, M.; Ryva, J.C.; Schmidt, D.J 241

High Levels of Group-Specific Component (Vitamin-D-Binding Protein) in the Cerebrospi-

nal Fluid of Infants Aged $<2$ Months

Katikaneni, L.P.; Emerson, D.L.; Goldschmidt-Clermont, P.J.; Loadholt, B.C.; Levkoff, A.H.; Galbraith, R.M 250

Action of Acetaldehyde on Glucose Metabolism of Newborn and Adult Erythrocytes

Ninfali, P.; Palma, F.; Piacentini, M.P.; Fornaini, G 256

Growth Hormone-Releasing Hormone. Studies in Cord Blood from Term Human New-

borns

Argente, J.; Acquafredda, A.; Cavallo, L.; Donnadieu, M.; Evain-Brion, D 264

Gastric Proteases in the Human Infant

Henschel, M.J.; Newport, M.J.; Parmar, V 268

Inhibitory Action of Bilirubin on Superoxide Production by Polymorphonuclear Leukocytes

Nakamura, H; Uetani, Y.; Komura, M.; Takada, S.; Sano, K.; Matsuo, T 273

Cardiovascular Status during Ketamine Anesthesia in the Fetal Lamb 
Lafond, J.S.; Fouron, J.-C; Bard, H 279

Acidemia Potentiates the Plasma Catecholamine Response to Hypoxemia in Fetal Sheep

Lewis, A.B.; Sadeghi, M 285

Influence of Food Intake during Late Gestation on Serum Lipids of Sows and Their

Progeny

Walsh Hentges, L.S.; Williams, A.C.; Mangham, W.A.; Martin, R.J

292

No. 6 Original Paper

Percutaneous Respiration in the Newborn Infant. Effect of Gestation and Altered Ambient

Oxygen Concentration

Cartlidge, P.H.T.; Rutter, N 301

Growth and Differentiation of Transplanted Rat Embryos in Intact, Diabetic and Hypophysectomized Hosts: Comparison with Their Growth in situ

Liu, L.; Russell, S.M.; Nicoll, C.S 307

Ontogenic Changes in Serum Immunoglobulins and C3 in Vitamin-D Deficient and Mal nourished Rats

Srimaruta, N.; Lee, P.C.; Lebenthal, E 317

IV Contents

Serum HDL Cholesterol and Apolipoprotein AI, All and B Levels in Singapore New-

borns

Saha, N.; Wong, H.B 93

Postnatal Development of Uterine Abnormalities in Mice Exposed to DES in Utero

Iguchi, T.; Takasugi, N 97

Effects of Isoproterenol-Induced Tachycardia on Myocardial Blood Flow and Glycogen in the Fetal Lamb

Tweed, W.A.; Davies, J.M.; Alexander, F.; Csorba, T.; Weber, S 104

The Newborn Rabbit: A Model for Studying Hypoxemia-Induced Renal Changes

Gouyon, J.-B.; Vallotton, M.; Guignard, J.-P 115

No. 3 Original Paper

Kallikrein Excretion: Relationship with Maturation and Renal Function in Human Neo-

nates at Different Gestational Ages

Vio, C.P.; Olavarria, F.; Krause, S.; Herrmann, F.; Grob, K 121

Serum and Lipoprotein Lipids of Fetal Pigs and Their Dams during Gestation as Compared with Man

Walsh Hentges, L.S.; Martin, R.J 127

Amino Acid Profiles during Development of the Fetal Rat

McEvoy-Bowe, E.; Hislop, J.; Wiggins, D.; Lund, P 135

Intestinal Macromolecular Transmission in the Young Rat: Influence of Protease Inhibitors

during Development

Telemo, E.; Weström, B.R.; Ekström, G.; Karlsson, B.W 141

Synthesis of Prostaglandins and Lipoxygenase Products by Rat Glomeruli during Development

Bensman, A.; Sraer, J.; Delarue, F.; Bens, M.; Vasmant, D.; Sraer, J.D 149

Transplacental Stimulation of Fetal Lung Maturation: Effect of Triiodothyronine in the

Female and Male Rabbit Fetus

Church, J.; Khafayan, E.; Chechani, V.; Sadiq, F.; Devaskar, S.; deMello, D.; Devaskar, U. 157

Effect of Maternal Fasting on Ovine Fetal and Maternal Branched-Chain Amino Acid

Transaminase Activities 
Liechty, E.A.; Barone, S.; Nutt, M 166

Effect of Hypophysectomy on Tissue Glycogen Concentrations in the Fetal Pig

Randall, G.C.B

174

No. 4 Original Paper

Composition of Weight Gain during Neonatal Period and Longitudinal Growth Follow-Up in Premature Babies

de Gamarra, M.E.; Schutz, Y.; Catzeflis, C; Freymond, D.; Cauderay, M.; Calame, A.;

Micheli, J.L.; Jequier, E

Respiratory Gases, Acid-Base Balance and Lactate Concentrations of the Midterm Human

Fetus

Bozzetti, P.; Buscaglia, M.; Cetin, I.; Marconi, A.M.; Nicolini, U.; Pardi, G.; Makowski, E.L.; Battaglia, F.C 188

Postprandial Glucose and Insulin Responses to Glucose Polymers by Premature Infants

Tucker, N.T.; Hodge, C; Choi, T.-S.; Lee, P.-C; Prihoda, T.J.; Lebenthal, E 198

VI Contents

Effect of Increased Intracranial Pressure on Blood Pressure, Heart Rate, Respiration and

Catecholamine Levels in Neonatal and Adult Rabbits

Ogilvy, C.S.; DuBois, A.J.B 327

Endogenous Opioid Effect on Breathing During Normoxia and Hypoxia in Developing

Swine

Moss, I.R.; Sugarman, L.M.; Goode, D.L 337

Oral Epidermal Growth Factor is Trophic for the Stomach in the Neonatal Rat

Falconer, J 347

Author Index 351

Subject Index 353

Suppl. 1 Energy Metabolism, Nutrition and Growth in Premature Infants

Editor: G. Due, Zurich 